\title{
Empirical Development of the Best Practices of Coaching and Mentoring for High Performance of Competency-based Education
}

\author{
Hideki Takei (Correspondence) \\ Dept. of Information Technology \& Administrative Management, Central Washington \\ University, U.S.A.
}

Peter Anthony

Dept. of Information Technology \& Administrative Management, Central Washington University, U.S.A.

Elizabeth Fountain

Dept. of Information Technology \& Administrative Management, Central Washington University, U.S.A.

\section{Luke Williams}

Dept. of Information Technology \& Administrative Management, Central Washington University, U.S.A.

Received: December 27, 2021

doi: 10.5296/ire.v10i1.19393
Accepted: February 2, 2022

Published: February 5, 2022

URL: https://doi.org/10.5296/ire.v10i1.19393

\begin{abstract}
Competency-based education (CBE) is different from traditional classroom instruction. For $\mathrm{CBE}$, organizing faculty development programs has been a mandatory requirement for higher education institutions to offer quality CBE. The programs' main goal is to make their faculty members effective coaches or mentors. Faculty development professionals in leading CBE higher education institutions have suggested developing the best coaching and mentoring practices to make faculty development programs more effective. This paper assessed and
\end{abstract}


revised our current best practices to improve our faculty development programs to develop better versions of the best practices.

Keywords: Competency-based Education, The Best Practices, Coaching, Mentoring

\section{Introduction}

Competency-based education (CBE) has been a rising trend of higher education institutions to serve the needs of underserved or non-traditional adult students. As CBE is different from traditional classroom instruction, organizing faculty development programs has been a mandatory requirement for the higher education institutions to offer quality $\mathrm{CBE}$ to the students (Klein-Collins, 2013; Ford, 2014; McClarty \& Gaertner, 2015; StrategyLabs, 2017). The programs' main goal is to make their faculty members effective coaches or mentors. Faculty development professionals in higher education institutions leading CBE have suggested developing the best coaching and mentoring practices to make faculty development programs more effective (Cunningham, Key, \& Capron, 2016; ODHE, 2021; Pearson, 2021).

The Master of Science program (MS-ITAM) of the Department of Information Technology and Administrative Management (ITAM) in Central Washington University (CWU) has offered a modified CBE program called FlexIT-Pro (FITP) since 2018. The model for FITP grew out of a modified performance-based modality first offered for undergraduate ITAM students in 2014. While we have provided faculty development training based on our own best coaching and mentoring practices, we have revised the best practices to improve our faculty development programs. This paper will present the revised best practices of coaching and mentoring based on our 3-year assessment of our original best practices.

\section{Competency-based Education}

CBE is different from traditional classrooms. CBE determines when students are ready to graduate from college, while formal instruction checks how students perform on measured competencies to determine when graduation occurs (Cbenetwork1, 2017). Namely, CBE focuses on knowledge application while traditional instruction focuses on knowledge acquisition. Therefore, if students are in CBE programs, their high grades can show their ability to apply the knowledge learned in the classroom to real-world situations (Klein-Collins, 2013; Ford, 2014; McClarty \& Gaertner, 2015; StrategyLabs, 2017).

Also, CBE can provide more flexible schedules and learning paths to meet individual needs because CBE uses tailored and self-paced instructions. CBE considers prior learning, prior knowledge, and mastery of competencies, while traditional instruction considers seat time or the number of hours spent in class. Therefore, $\mathrm{CBE}$ can accelerate the time necessary to complete the program. Many CBE students can complete the program much faster than the expected learning time because they are more responsible. CBE allows students to enjoy the flexibility to combine learning with job and family responsibilities. Also, coaches and the students tend to share learning responsibility for better buy faster learning. In CBE, coaches serve as facilitators and supporters instead of giving them knowledge (Cunningham, Key, \& Capron, 2016; ODHE, 2021; Pearson, 2021).

As CBE assesses students' competencies, it needs to specify competencies to assess students' 
competencies correctly. First, CBE should introduce effective prior learning assessment (PLA) to determine students' learning and competencies. Then, it should assess students' competencies appearing throughout CBE (LuminaFoundation, 2016). While CBE focuses on the skills and abilities required in the real world, it should use various measurements for the assessment. While there is no right and wrong measurement, effective measurements must assess students' ability to integrate, synthesize, and use the knowledge and skills required in the real world. CBE should measure students' progress by not the amount of time spent in a classroom but an actual demonstration of competencies. Leading CBE offering institutions have suggested developing benchmarks for mastery (AACN, 2020; Mathematica, 2021).

Generally speaking, there are four components in CBE design: learning resources for students, effective assessment of competencies, clear faculty roles, and clearly defined traits of successful students (Kellogg, 2018; Peek, 2021). CBE faculty can measure students' competencies through objective assessments such as questioning or performance-based assessments. Performance-based assessments include papers, group activities, observation, analytics, and projects. A mixture of the two assessment types will help the faculty develop a benchmark for each student. In CBE, there are two types of faculty roles: coaching and mentoring. Coaches are learning facilitators, while mentors are learning supporters. Four essential traits for coaches and mentors are self-direction, resilience and dedication, work experience, and previous learning (Cunningham, Key, \& Capron, 2016; LuminaFoundation, 2016; Mathematica, 2021).

\section{Required Traits of CBE Faculty}

The basic functions of CBE faculty are coaching and mentoring, competency assessment, progress monitoring, and feedback. CBE faculty has seven required traits to make these functions more effective.

First, CBE faculty should be experts in chosen fields and life experiences. Especially, coaches should have their areas of expertise while mentors should show their life experiences for mentoring students. Such professionalism is required for CBE faculty as they coach and mentor professionals to develop competencies by applying their knowledge and skills to practical issues. Also, they need to utilize their own life experiences to become mindful of other persons' life situations. Of course, they must continuously improve their professional expertise and life experience (ODHE, 2021; Pearson, 2021).

Second, CBE faculty should offer students opportunities to demonstrate real-world skills and abilities. They should facilitate knowledge application to let their students demonstrate competencies (ODHE, 2021; Pearson, 2021).

Third, they should be learning partners who share learning responsibilities with students. As CBE is personalized learning, they also need to know various learning styles to support students in combining learning with job and family responsibilities (Kellogg, 2018; Calstate, 2021; Peek, 2021).

Fourth, they should be able to measure competencies in multiple ways. First, they need to know appropriate measurements for students' prior learning. Then, they should master five dimensions of learning outcomes of $\mathrm{CBE}$ to measure competencies throughout $\mathrm{CBE}$ programs. The dimensions are applied learning, intellectual skills, specialized knowledge, 
broad knowledge, and civic learning. These include three types of students' competence: knowledge, skills/behaviors, and attitudes/values (ODHE, 2021; Pearson, 2021).

Fifth, in addition to the appropriate ways of competency assessment, they should know various ways to serve the needs of non-traditional or underserved adult students to bring their knowledge out to apply as competencies. They should know appropriate coaching and mentoring techniques to support students' self-direction in learning, resilience and dedication to learning, and applications of work experiences and previous learning (ODHE, 2018; Cbenetwork2, 2021).

Sixth, they should understand the principles, characteristics, practices, and policies of CBE to develop effective learning materials or modify existing materials for better students' learning. Also, understanding these will help them to let students fully accept learning objectives, systems, rules, and assessment criteria (LuminaFoundation, 2016; Kellogg, 2018; Peek, 2021).

Finally, they must work together with staff members to develop optimum learning environments and systems for students. It is ideal for coaches and mentors to actively participate in curriculum developments, modifications, and faculty development programs (O’Sullivan \& Bruce, 2014; Peek, 2021).

\section{CBE Faculty Development}

As we mentioned, leading CBE institutions have implemented faculty development programs to make their faculty members effective coaches and mentors.

In general, through effective faculty development programs, CBE faculty can develop their skills to pace monitor, intervene, and support to encourage students to stay on track. Also, they will learn effective ways of inspiring and motivating students. To assess students' competencies correctly, they will learn ways to set benchmarks of student competencies. Faculty development programs will encourage participants to apply their career and life experiences to support students' career development. They will learn teaching methods to support students' learning by understanding active and guided learning modes. Especially, the active learning model is critical as it brings students' knowledge and previous learning out to apply in real situations. Faculty will also learn various ways to let students reflect, analyze, judge, resolve, discover, interact, and create throughout CBE programs (Ford, 2014; Cunningham, Key, \& Capron, 2016; LuminaFoundation, 2016; AACN, 2020; Mathematica, 2021).

In addition to continuous faculty development, many CBE programs have tried to develop the best coaching and mentoring practices. The best practices will be guidelines that will support the self-learning and development of coaches and mentors. In general, the best practices of coaching have seven areas: assessment, feedback, career preparation, field expertise, communication, team-up, and self-management. Similarly, the best mentoring practices have six areas: assessment, feedback, career preparation, life expertise, communication, and team-up (Ford, 2014; Cunningham, Key, \& Capron, 2016; LuminaFoundation, 2016; AACN, 2020; Mathematica, 2021). 


\section{FlexIT-Pro Program}

The Master of Science program (MS-ITAM) of the Department of Information Technology and Administrative Management (ITAM) in Central Washington University (CWU) has offered FlexIT-Pro (FITP). It is a modified CBE program that the Master of Science program (MS-ITAM) of the Department of Information Technology and Administrative Management (ITAM) in Central Washington University (CWU) has offered since 2018. The model for FITP grew out of a modified performance-based modality first offered for undergraduate ITAM students in 2014.

In FITP, the faculty member called "Content Coach" is assigned to a specific course within their academic and professional expertise, who coaches students on course content and evaluates their competencies related to the course outcomes.

The faculty member called "Mentor" is assigned to support a caseload of students from intake and orientation through a degree or program completion. Mentors assist with learning strategies, time management, program planning, and career planning; and support students in communicating effectively with Content Coaches. They also serve as faculty advisors for the students assigned to them.

We call faculty who has served as Content Coach and/or Mentor "Core Faculty," who is engaged in the overall development of the FITP modality.

\section{The Best Practices of Coaching and Mentoring for FITP}

Core faculty members of FITP developed best practices of coaching and mentoring three years ago. Since then, FITP has used the best practices for all FITP faculty members to offer their students great learning experiences. New faculty members of FITP have taken new faculty orientations to learn the best practices with many examples with the core faculty. If our coaches and mentors struggle, the core faculty will offer them several development seminars for improvement.

The core faculty members formally organized a faculty development committee (FDC) to reorganize faculty development programs for FITP. Our current best practices for coaches focus on assessment, feedback, communication, team-up, and self-management. Our best practices for mentors have focused on feedback, communication, and team-up.

In 2021, FDC decided to revise our current best practices for better education at FITP. The FDC members assessed the current best practices based on historical reports of student surveys, faculty development records, and minutes of focus group discussions.

\section{Assessment Method}

While our best practices have worked very well, we have used them for three years. We decided to revise the best practices with our accumulated experience and information about CBE instructions. Especially, revising the best practices is important for upgrading our programs to executive CBE.

To revise the practices, we used three information sources: accumulated students' comments and suggestions from regular surveys, collected information through various meetings with coaches and mentors, and records of focus group meetings. 


\section{Assessment of the Current Best Practices for Coaching}

According to student input, unclear distinctions of formative feedback and summative feedback seemed to confuse our students. For example, our students tend to take formative feedback as a part of summative feedback. They asked too much for the formative feedback, which will increase coaches' workload unnecessarily. They suggested a standard format and better facilitation for better interactions with coaches for synchronous sessions. Additionally, many of them suggested virtual office hours to find more opportunities to learn applied knowledge and real experiences of coaches' expertise. Finally, they implied that they would appreciate it if they could have some suggestions for their career advancement through their education.

According to our meeting records, new coaches asked for clear distinctions between formative and summative feedback with examples. Especially, they wanted to know the types of formative feedback, the feedback's know-how, and the timing of the feedback. To understand these comprehensively, they suggested a flow chart showing these. Some coaches wanted to have the best practices or suggested ways of observing students' competency demonstrations. Many coaches asked for the best practices of synchronous sessions and virtual meetings for better facilitation and designs for active students' participation and learning. They wanted to know ways of initiating two-way communications for active and meaningful feedback and communications. While our faculty seemed to be comfortable with the best practices of team-up, some of them suggested the best practices of ongoing communication for better collegiality. They seemed to be fine with the best practice of self-management; however, they seemed to look for refreshers and joint teaching evaluation assessments for better instructions. They wanted us to develop functional definitions of coordinator, coach, and mentor to prevent functional confusion. Many faculty members showed strong interest in continuous improvement and development of their expertise for better instructions and meaningful suggestions for students' career preparation.

Our focus groups suggested clearer descriptions and best formative and summative feedback practices. Additionally, they suggested effective feedback training for new coaches. They asked for the best practices of synchronous sessions and virtual meetings with better students' participation, facilitation, instructional materials, and formats. They suggested behavioral training for students to make them active communicators before the initial contact by coaches. Finally, they loved to continuously improve and develop knowledge and experience of their field of expertise. They asked for such improvement and development opportunities. They all agreed that they needed to develop their skills to support students' career preparations.

\section{Assessment of the Current Best Practices for Mentoring}

Our students looked for practical suggestions or consultations for career preparation. Especially, they loved to learn from mentors' real-life experiences and fields of expertise for their career planning. Another thing was they wanted to know a clear functional distinction between coaches and mentors.

Our meeting records showed their need for the best practices of assessing students' attitudes and behaviors. Especially, they wanted to assess students' emotional, mental, or even life 
conditions through their attitudes and behaviors to make better feedback and support. They also asked for the best practices of tracking students' performance and schedules for better intervention, facilitation, and connecting. To be a great middle person, they wanted to know the clear relationship with coaches, students, and mentors for better communication and feedback. They wanted to know the clear relationship with the coordinator and coaches for better team-up and collegiality. Finally, they asked for the best practices of supporting students' career development and emotional growth.

Our focus group meeting records showed critical elements which we should add to the current best practices. First, they needed the best practices of assessing the behaviors and attitudes of students. Second, they asked for the best practices of tracking students' performance and schedules for better intervention, facilitation, and bridging. Finally, they are interested in developing their skills to support students' career development and emotional growth.

\section{Revisions of the Current Best Practices}

Our assessments of the current best practices showed us opportunities for improving the educational performance of FITP. Based on the assessment, we developed revised best practices for coaching and mentoring. Appendixes 2 and 3 show the revised versions.

Our revised best practices for coaching include several critical additional components. First, we added additional explanations to ensure clear distinctions between formative and summative feedback. Knowing the differences will allow them to offer the best possible feedback formats on time. Suppose they can explain the differences and importance of the two types of feedback when they begin classes. In that case, the students can use feedback to continuously improve their learning towards the summative feedback. We also refined the best practices of feedback timing and modes. As additional information, we added some know-how and examples of effective feedback.

Second, we added practical suggestions for synchronous sessions for better participation, facilitation, and settings. We also suggested several synchronous session platforms, office hours, and meetings.

Third, we added the best practices of continuously improving skills and knowledge in their fields of expertise, which coaches can use for instructions and career advising. We believe utilizing their expertise in career advising and consultation is an important part of educational benefits for our students.

Fourth, we revised the best communication practices to initiate, develop, and maintain active two-way communication between coaches and students. The revised practices focus on ensuring the effectiveness of feedback and regular communications, including career advising. In addition, we added the best practices of ongoing communication for good collegiality with clearer explanations of functional differences among a coordinator, coaches, and mentors.

Finally, we added the best practices of self-management of coaches to maximize instructional effectiveness and efficiency for our students. The practices include several suggestions such as time management, communication rules, joint student survey reviews, taking refresher training, and developing ways of being self-learners. 
Our revised best practices for mentoring also have critical additional components. First, we added the best practices of life experience development for better mentoring and career consultations. The best practices include several practices that mentors can use to support students who face life and career development difficulties.

Second, we clarified mentors' responsibilities, duties, and positions between students and coaches. Especially, knowing best practices to be a middle person between coaches and students will help mentors perform their functions. This will also help improve collegiality among a coordinator, mentors, and coaches.

Finally, we added the best practices of assessing students' attitudes and behaviors, indicating the students' competency. The revised best practices will let mentors understand students' emotional and mental conditions through their attitudes and behaviors. The best practices include practical ways to track students' progress for better intervention and assessment.

\section{Conclusion}

We revised our best practices for coaches to improve, particularly feedback, synchronous sessions, continuous improvement of their field of expertise, communication, and self-management. We revised our best practices for mentors to improve, particularly continuous accumulations of their life experience, mentorship, and assessment.

Revising our best practices is not the ending point, and rather, it is a starting point to maintain our competitive edge in CBE. Our revised best practices will improve the overall quality of FITP if we can use the practices wisely with coaches and mentors. We believe we need to revise our faculty development programs as well. We will also develop instructional know-how for each class for better instructions and time management of our coaches.

\section{References}

AACN. (2020, November 5). The Essentials: Core Competencies for Professional Nursing Education. Retrieved April 2021, from AACN: https://www.aacnnursing.org/portals/42/downloads/essentials/essentials-draft-document.pdf

Calstate. (2021). Statement on Competency-based Assessment of Student Learning. Retrieved April 2021, from calstate:

https://www.calstate.edu/csu-system/faculty-staff/academic-senate/Documents/reports/Statement_on_Com petency-based_Assesment_of_Student_Learning.pdf

Cbenetwork1. (2017, September). Quality Framework for Competency-Based Education Programs. Retrieved April 2021, from cbenetwork: http://www.cbenetwork.org/wp-content/uploads/2018/09/Quality-Framework-for-Competency-Based-Educ ation-Programs-Updated.pdf

Cbenetwork2. (2021). What is Competency-Based Education? Retrieved April 2021, from cbenetwork: https://www.cbenetwork.org/competency-based-education/

Cunningham, J., Key, E., \& Capron, R. (2016). An evalua on of competency- based educa on programs: A study of the development process of competency- based programs. Competency-based Education(1), 130-139. https://doi.org/10.1002/cbe2.1025

Ford, K. (2014, October 24). Competency-Based Education History, Opportunities, and Challenges. 
Retrieved

April

2021,

from

umgc:

https://www.umgc.edu/documents/upload/competency-based-education.pdf

Kellogg, S. (2018). Competency Based Education: Best Practices and Implementation Strategies for Institutions of Higher Education. Retrieved March 2021, from Concordia University St. Paul: https://core.ac.uk/download/pdf/235302572.pdf

Klein-Collins, R. (2013, November). Sharpening Our Focus on Learning: The Rise of Competency-Based Approaches to Degree Completion. Retrieved April 2021, from learningoutcomesassessment: https://www.learningoutcomesassessment.org/wp-content/uploads/2019/02/OccasionalPaper20.pdf

LuminaFoundation. (2016, February). EXPANDING COMPETENCY-BASED EDUCATION FOR ALL LEARNERS. Retrieved April 2021, from luminafoundation: https:/www.luminafoundation.org/files/resources/expanding-cbe-for-all.pdf

Mathematica. (2021). Best Practices in Competency-Based Education: Lessons from Three Colleges. Retrieved March 2021, from Central Texas College: https://content.ctcd.edu/downloads/online/files/CBE_BestPractices_IFBrief.pdf

McClarty, K., \& Gaertner, M. (2015, April). MEASURING MASTERY BEST PRACTICES FOR ASSESSMENT IN COMPETENCY-BASED EDUCATION. Retrieved April 2021, from eric: https://files.eric.ed.gov/fulltext/ED557614.pdf

ODHE. (2021). Competency Based Education. Retrieved March 2021, from Ohio Department of Higher Education:

https://www.ohiohighered.org/sites/ohiohighered.org/files/uploads/board/condition-report/2016-Conditions -Report_FINAL.pdf

O'Sullivan, N., \& Bruce, A. (2014, September). Teaching and learning in competency-based education. Retrieved April 2021, from researchgate: https://www.researchgate.net/publication/269810124_Teaching_and_Learning_in_Competency_Based_Ed ucation

Pearson. (2021). Defining Competencies and Outlining Assessment Strategies for Competency Based Education Programs. Metrieved March 2021, from Pearson: https:/www.pearson.com/content/dam/one-dot-com/one-dot-com/ped-blogs/wp-content/pdfs/584G245_C BE-Assessment_WP_WEB_f.pdf

Peek, K. (2021). Competency Based Education Made Easy. Retrieved March 2021, from sccollege: https://www.sccollege.edu/Departments/AcademicSenate/CICouncil/Documents/CBE\%20Handbook\%20f or\%2011-2-20.pdf

Soares, L. (2012, June). A 'Disruptive' Look at Competency-Based Education. Center for American Progress, 1-12. Retrieved July 2021, from https://cdn.americanprogress.org/wp-content/uploads/issues/2012/06/pdf/comp_based_education.pdf StrategyLabs. (2017). UNDERSTANDING COMPETENCY-BASED EDUCATION. Retrieved April 2021, from ecs: https://www.ecs.org/wp-content/uploads/CBE-Toolkit-2017.pdf 
Appendix A

\section{Current Best Practices of Coaching}

\begin{tabular}{|l|l|}
\hline Coaches & \\
\hline Assessment & $\begin{array}{l}\text { Establish in your course and with individual students as they enroll in your course, your } \\
\text { expectations for formative feedback. Formative feedback helps students develop their } \\
\text { final assessments; it is provided before and is separate from grading. In FlexIT/FlexIT } \\
\text { Pro you provide opportunities for formative feedback as part of the Content Coach } \\
\text { interaction expectations that contribute to the students' final grades. }\end{array}$
\end{tabular}

- Drafts: In writing-intensive courses, formative feedback might take the form of working with drafts. Structuring this work with drafts can be very beneficial. For example, some final assessments have major sections that you might want to make sure are on track before students move on to the next step or to the complete assessment. Rather than providing complete issue-by-issue feedback using track changes, which could easily be revised by the student just accepting the changes, you might want to provide one or two specific comments (or refer them to the content/resources - ie. CWU Writing Center, e-tutoring, Canvas modules, textbook, and offering a chance to meet with them; for their own learning) and add a comment that the student needs to go through the rest of the document to revise other similar issues accordingly - which provides the student the knowledge and empowers self-learning and development. If your course has periodic check points throughout the course that work as formative feedback, that may be enough for draft review; whereas other courses might be more adaptable to draft review of a final assessment before the student actually submits for grading.

- Concept/practice quizzes: In more technical courses, setting up concept quizzes or practice quizzes can help students test themselves on specific knowledge areas. This can make for a messy gradebook, however, so be sure to indicate clearly that these quizzes are not part of the final grade.

- Preliminary steps/journal entries/reflections: Some courses build in shorter assignments, including preliminary steps, journal entries or brief reflection papers, that track student learning as part of the progress toward the final assessment. As with quizzes, be sure to indicate clearly that these assignments are not part of the final grade.

- Synchronous sessions (Zoom, Skype, Teams): Several faculty have found that scheduling synchronous sessions creates valuable give-and-take regarding formative feedback. These 1:1 sessions are held in real time, giving the opportunity to deal with questions and clarify expectations quickly. For classes with multiple students on the same timeframe, group study sessions or Q\&A sessions can also be useful.

Final Assessment Feedback/Grading: Final assessments are the tool for summative 


\begin{tabular}{|c|c|}
\hline & $\begin{array}{l}\text { feedback; this is feedback given to students as to whether or not the projects, papers, etc., } \\
\text { produced for the course meet or exceed the standard for demonstrating competency. Final } \\
\text { assessments can be a single large project or paper, a portfolio of shorter projects or } \\
\text { papers, or a combination of tests, projects, and papers. They can be submitted as single or } \\
\text { multiple entries. In some classes, final assessments are required to be submitted in a } \\
\text { prescribed sequence of steps to ensure students are on track before moving forward. } \\
\text { - Provide feedback/grades preferably within } 3 \text { days; but no later than } 5 \text { days. If } \\
\text { grading will take longer than } 5 \text { days, communicate with the student; copy the } \\
\text { program coordinator and/or the student's mentor. Students are often on tight } \\
\text { deadlines for grades for financial aid or other reasons, and we track this closely. } \\
\text { If a student does not achieve a minimum passing grade of } 80 \% \text { on first } \\
\text { submission of the final assessment(s); then the student must resubmit to raise } \\
\text { his/her grade to achieve the } 80 \% \text { passing grade for FlexIT/FlexIT Pro courses. } \\
\text { With this situation, you might want to offer a meeting/virtual meeting to go over } \\
\text { the results and how to improve for a passing grade. } \\
\text { Students who earn } 80 \% \text { or higher on their first attempt do not get a second } \\
\text { attempt only to raise the grade. } \\
\text { Suggestions but you may have a method you prefer: } \\
\text { o Encourage students to review the requirements of the final assessment(s) } \\
\text { - }\end{array}$ \\
\hline Feedback & $\begin{array}{l}\text { Send a welcome message in the discussions as the first contact, then follow-up with } \\
\text { sending students a course policy statement with your expectations, then just back and } \\
\text { forth communication as needed. Providing a video for every final assessment and the } \\
\text { expectations for each assessment can be useful for students and make your review } \\
\text { process smoother. } \\
\text { Post a welcome video as well as adding short articles of interest or relevance (ungraded) } \\
\text { throughout the course pertinent to specific modules can be helpful to students for } \\
\text { understanding different concepts - and can make the course more interesting/memorable } \\
\text { for the students. Also, you might want to suggest students keep a "proverbial" tool bag of } \\
\text { articles, concepts, ideas as they move through the course to make their own opinions } \\
\text { stronger in the final assessment(s). } \\
\text { Respond to students' communication/questions preferably within } 24 \text { hours; but no later } \\
\text { than } 48 \text { hours. If you don't have the answer within that amount of time, please respond } \\
\text { indicating that you will follow-up with the answer so they know you got the } \\
\text { communication and are working on the answer. Then, put the issue on your to-do list as a } \\
\text { reminder that you need to clear the communication. }\end{array}$ \\
\hline & Finalizing Grading: Submit a Grading Form at this link:----------------------------- \\
\hline
\end{tabular}




\begin{tabular}{|c|c|}
\hline Career preparation & None \\
\hline Field expertise & None \\
\hline Communication & $\begin{array}{l}\text { Post a Content Coach Welcome/Expectations video in your classroom (ie. panopto, zoom, } \\
\text { etc.) that addresses: (1) Why the student is taking this course (purpose and importance of } \\
\text { the course content); (2) What is expected for communication with you as Content Coach; } \\
\text { (3) What is expected with the Final Assessment(s); and (4) anything else you briefly want } \\
\text { to address to help the student be successful in your class. } \\
\text { Respond to students' communication/questions preferably within } 24 \text { hours; but no later } \\
\text { than } 48 \text { hours. } \\
\text { Inform students (and the program coordinator) if you will be out of communication for } \\
\text { more than } 24 \text { hours, or if your response time will be slower than usual. } \\
\text { If you are going to be out-of-the-office (vacation, emergency, medical, travel, etc.) let } \\
\text { FlexIT program coordinator know and your plans/needs during that time. Also, let your } \\
\text { students know. }\end{array}$ \\
\hline Team-up & $\begin{array}{l}\text { Inform students (and the program coordinator) if you will be out of communication for } \\
\text { more than } 24 \text { hours, or if your response time will be slower than usual. } \\
\text { If you are going to be out-of-the-office (vacation, emergency, medical, travel, etc.) let } \\
\text { FlexIT program coordinator know and your plans/needs during that time. Also, let your } \\
\text { students know. }\end{array}$ \\
\hline Self-management & $\begin{array}{l}\text { Time Management: You only have } 24 \text { hours in the day minus sleep time to balance your } \\
\text { life, school, work, family, hobbies, exercise, etc. If something (work, school, family, etc.) } \\
\text { is an immediate need/deadline - do it immediately! If something is an as the opportunity } \\
\text { allows task, then jot it down for a reminder of something you need to do and when it } \\
\text { needs to be done by. Keep track and cross off tasks (personal/professional) as completed. } \\
\text { Note: If you are going to be out-of-the-office (vacation, emergency, medical, travel, etc.) } \\
\text { let FlexIT program coordinator know and your plans/needs during that time. Also, let } \\
\text { your students know. }\end{array}$ \\
\hline
\end{tabular}




\section{Appendix B}

\section{Current Best Practices of Mentoring}

\begin{tabular}{|c|c|}
\hline Mentors & \\
\hline Assessment & None \\
\hline Feedback & $\begin{array}{l}\text { Advise students in plenty of time before registration, graduation (folder records check), } \\
\text { completion of classes, IPs (including time before auto "F" after 1-year term-to-term) } \\
\text { deadlines to ensure students get accurate advice. When unsure of how to respond to a } \\
\text { student/advise, check with FlexIT Program Coordinator or other mentors for advice. } \\
\text { Ensure students understand the requirement to complete at least one course during current } \\
\text { enrollment term; and monitor that they don't have more than } 16 \text { outstanding credits they } \\
\text { are working on before allowing them to register for next term. However, } 16 \text { outstanding } \\
\text { credits is a guideline and we as mentors will know each student's specific situation and } \\
\text { whether we can realistically think the student will be ok with being over the } 16 \text { credits. }\end{array}$ \\
\hline Career preparation & None \\
\hline Life expertise & None \\
\hline Communication & $\begin{array}{l}\text { Respond to students' communication/questions preferably within } 24 \text { hours; but no later } \\
\text { than } 48 \text { hours. If you don't have the answer within that amount of time, please respond } \\
\text { indicating that you will follow-up with the answer so they know you got the } \\
\text { communication and are working on the answer. Then, put the issue on your to-do list as a } \\
\text { reminder that you need to clear the communication. } \\
\text { Be a go-between with content coaches when students have praise, concerns, or questions } \\
\text { about a course, etc. to help ensure content coaches' and students' communication is } \\
\text { smooth and informative as needed. } \\
\text { Respond to communication with content coaches within } 24 \text { hours (preferably within a } \\
\text { few hours, but no later than } 48 \text { hours to assist with course or student concerns/questions. } \\
\text { You only have } 24 \text { hours in the day minus sleep time to balance your life, school, work, } \\
\text { family, hobbies, exercise, etc. If something (work, school, family, etc.) is an immediate } \\
\text { need/deadline - do it immediately! If something is an as the opportunity allows task, then } \\
\text { jot it down for a reminder of something you need to do and when it needs to be done by. } \\
\text { Keep track and cross off tasks (personal/professional) as completed. }\end{array}$ \\
\hline Team-up & $\begin{array}{l}\text { Keep in communication with FlexIT Program Coordinator to ensure understanding of } \\
\text { polices, processes, and procedures to be an informed team player with assisting content } \\
\text { coaches. } \\
\text { Be a go-between with content coaches when students have praise, concerns, or questions } \\
\text { about a course, etc. to help ensure content coaches' and students' communication is }\end{array}$ \\
\hline
\end{tabular}




\begin{tabular}{|l|l|}
\hline smooth and informative as needed. \\
Share concerns/questions/suggestions from Content Coaches with Program Coordinator; \\
and vice versa to ensure we do the best we can together as a team for the program. \\
If you are going to be out-of-the-office (vacation, emergency, medical, travel, etc.) let \\
FlexIT program coordinator know and your plans/needs during that time.
\end{tabular}

\section{Appendix C}

\section{Revised Best Practices of Coaching}

\begin{tabular}{|c|c|}
\hline Coaches & \\
\hline Assessment & $\begin{array}{l}\text { Formative Assessment: } \\
\text { - As they enroll in your course, establish your expectations for formative } \\
\text { assessment, which helps students develop their final (summative) assessments. } \\
\text { You offer the formative feedback before grading (Summative assessment). } \\
\text { - In FlexIT/FlexIT Pro you provide students opportunities for formative assessment } \\
\text { as part of the Content Coach interaction expectations. The interaction } \\
\text { expectations will contribute to the students' final grades. } \\
\text { Methods of the formative assessment: } \\
\text { Drafts assessment: In writing-intensive courses, formative assessment might } \\
\text { take the form of working with drafts. Structuring this work with drafts can be } \\
\text { very beneficial. For example, some final assessments have major sections that } \\
\text { you might want to make sure are on track before students move on to the next } \\
\text { step or to the complete assessment. Rather than providing complete } \\
\text { issue-by-issue feedback using track changes, which could easily be revised by } \\
\text { the student just accepting the changes, you might want to provide one or two } \\
\text { specific comments (or refer them to the content/resources - ie. CWU Writing } \\
\text { Center, e-tutoring, Canvas modules, textbook, and offering a chance to meet } \\
\text { with them; for their own learning) and add a comment that the student needs to } \\
\text { go through the rest of the document to revise other similar issues accordingly - } \\
\text { which provides the student the knowledge and empowers self-learning and } \\
\text { development. If your course has periodic check points throughout the course that } \\
\text { work as formative assessment, that may be enough for draft review; whereas } \\
\text { other courses might be more adaptable to draft review of a final assessment } \\
\text { before the student actually submits for grading. } \\
\text { - } \\
\text { or pon help students test themselves on specific knowledge }\end{array}$ \\
\hline
\end{tabular}




\begin{tabular}{|c|c|}
\hline & 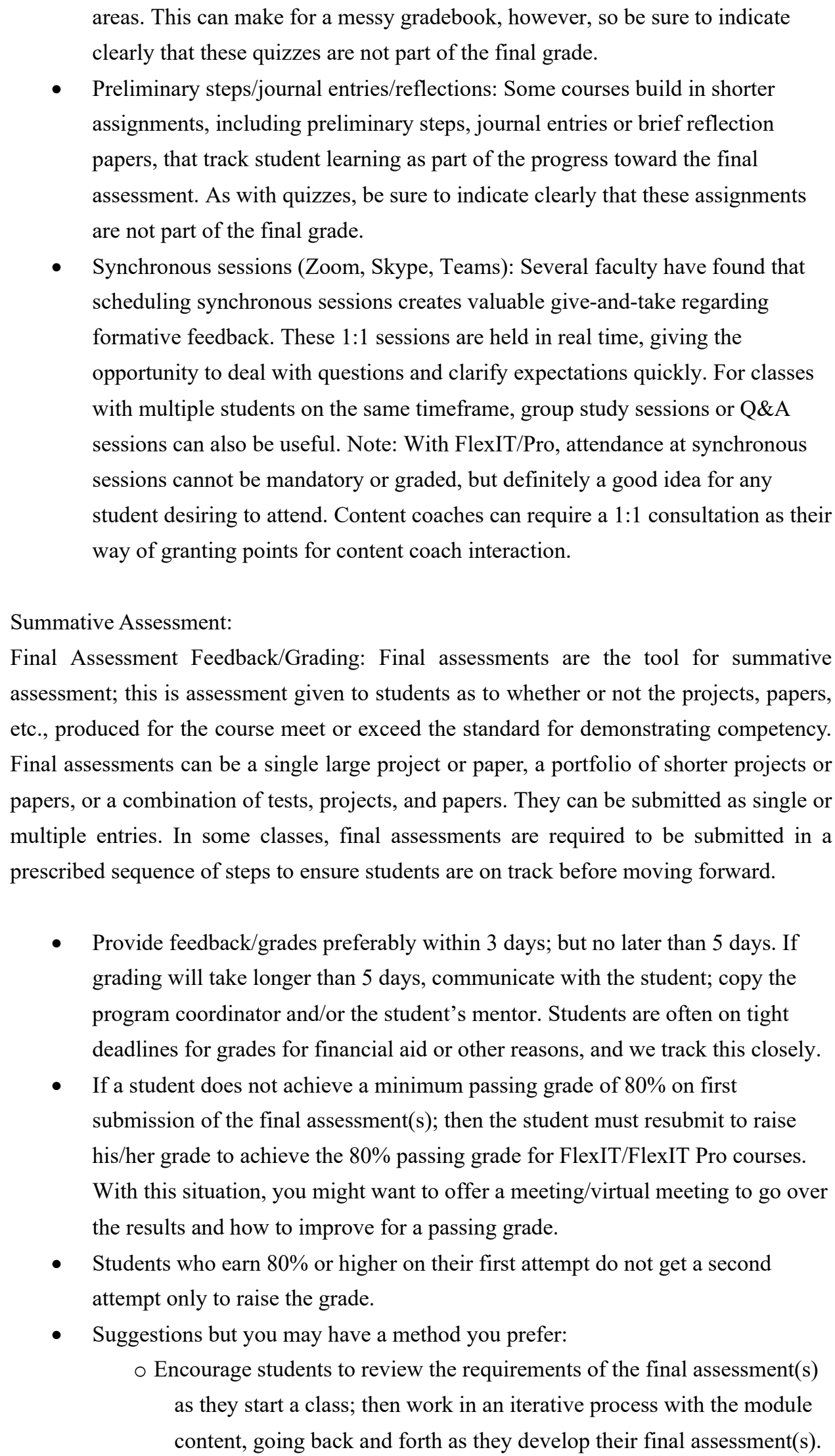 \\
\hline Feedback & Behavioral Training for Effective Mutual Feedback: \\
\hline
\end{tabular}




\begin{tabular}{|c|c|}
\hline & $\begin{array}{l}\text { Send a welcome message in the discussions as the first contact, then follow-up with } \\
\text { sending students a course policy statement with your expectations, then just back and } \\
\text { forth communication as needed. } \\
\text { Active Feedback: } \\
\text { Providing a video for every final assessment and the expectations for each assessment } \\
\text { can be useful for students and make your review process smoother. } \\
\text { Post a welcome video as well as adding short articles of interest or relevance (ungraded) } \\
\text { throughout the course pertinent to specific modules can be helpful to students for } \\
\text { understanding different concepts - and can make the course more interesting/memorable } \\
\text { for the students. Also, you might want to suggest students keep a "proverbial" tool bag of } \\
\text { articles, concepts, ideas as they move through the course to make their own opinions } \\
\text { stronger in the final assessment(s). } \\
\text { Offer your feedback (responses) to students' communication/questions preferably within } \\
24 \text { hours; but no later than } 48 \text { hours. If you don't have the answer within that amount of } \\
\text { time, please respond the students indicating that you will follow-up with the feedback. } \\
\text { Make sure that you put the issue on your to-do list as a reminder. }\end{array}$ \\
\hline Communication & $\begin{array}{l}\text { First Communication: } \\
\text { Post a Content Coach Welcome/Expectations video in your classroom (ie. Panopto, } \\
\text { zoom, etc.) that addresses: } \\
\text { (1) Why the student is taking this course (purpose and importance of the course } \\
\text { content) } \\
\text { (2) What is expected for communication with you as Content Coach } \\
\text { (3) What is expected with the Final Assessment(s) } \\
\text { (4) Anything else you briefly want to address to help the student be successful } \\
\text { in your class. } \\
\text { - Respond to students' communication/questions preferably within } 24 \text { hours; but no } \\
\text { later than } 48 \text { hours. } \\
\text { Inform students (and the program coordinator) if you will be out of } \\
\text { FlexIT program coordinator know and your plans/needs during that time. Also, let your } \\
\text { students know. } \\
\text { Out-of-the-office Rule: } \\
\text { than usual. }\end{array}$ \\
\hline
\end{tabular}




\begin{tabular}{|c|c|}
\hline Team-up & $\begin{array}{l}\text { Team Members } \\
\text { - Students } \\
\text { - Mentors (Colleagues) } \\
\text { - } \text { FDC members } \\
\text { - FlexIT-Pro Coordinator } \\
\text { - ITAM Staff Members } \\
\text { - Your Family Members } \\
\text { Communication for Teamwork } \\
\text { - Inform students (and the program coordinator) if you will be out of } \\
\text { communication for more than } 24 \text { hours, or if your response time will be slower } \\
\text { than usual. } \\
\text { - If you are going to be out-of-the-office (vacation, emergency, medical, travel, } \\
\text { etc.) let the FlexIT program coordinator know and your plans/needs during that } \\
\text { time. Also, let your students know. }\end{array}$ \\
\hline Self-management & $\begin{array}{l}\text { You are the priority. } \\
\text { Do what's right for you to do what's right for others. } \\
\text { Time Management: You only have } 24 \text { hours in the day minus sleep time to balance your } \\
\text { life, school, work, family, hobbies, exercise, etc. If something (work, school, family, etc.) } \\
\text { is an immediate need/deadline - do it immediately! If something is an as the opportunity } \\
\text { allows task, then jot it down for a reminder of something you need to do and when it } \\
\text { needs to be done by. Keep track and cross off tasks (personal/professional) as completed. } \\
\text { Note: If you are going to be out-of-the-office (vacation, emergency, medical, travel, etc.) } \\
\text { let the FlexIT program coordinator know and your plans/needs during that time. Also, let } \\
\text { your students know. }\end{array}$ \\
\hline Career Preparation & $\begin{array}{l}\text { Write down your own experience and knowledge about career preparations. Use the } \\
\text { information to support students. } \\
\text { Apply knowledge from your own expertise development activities (conferences, training, } \\
\text { etc.) when you consult with students regarding their career preparation. } \\
\text { Find professionals who can support your students' career development. }\end{array}$ \\
\hline Field Expertise & $\begin{array}{l}\text { Develop your expertise development plan and share with FDC members and the } \\
\text { FlexIT-Pro coordinator. Then, ask for financial support. } \\
\text { Develop joint projects (research or training) with other coaches or mentors. Share the }\end{array}$ \\
\hline
\end{tabular}




\begin{tabular}{|l|l|}
\hline $\begin{array}{l}\text { projects with FDC members and the FlexIT-Pro coordinator. Then, ask for financial } \\
\text { support. }\end{array}$ \\
$\begin{array}{l}\text { Socialize with our advisory board members to access the latest industrial situations and } \\
\text { develop human network. }\end{array}$ \\
\hline
\end{tabular}

\section{Appendix D}

\section{Revised Best Practices of Mentoring}

\begin{tabular}{|l|l|}
\hline Mentors & $\begin{array}{l}\text { Rapport Development: } \\
\text { Send a welcome message as the first contact, then follow-up with sending students your } \\
\text { rules and expectations, then just back and forth communication as needed. } \\
\text { Pro-active Mentoring: } \\
\text { Advise students in plenty of time before registration, graduation (folder records check), } \\
\text { completion of classes, IPs (including time before auto "F" after 1-year term-to-term) } \\
\text { deadlines to ensure students get accurate advice. When unsure of how to respond to a } \\
\text { student/advise, check with the FlexIT Program Coordinator or other mentors for advice. }\end{array}$ \\
$\begin{array}{l}\text { Ensure students understand the requirement to complete at least one course during current } \\
\text { enrollment term; and monitor that they don't have more than 16 outstanding credits they } \\
\text { are working on before allowing them to register for next term. However, 16 outstanding } \\
\text { credits is a guideline and we as mentors will know each student's specific situation and } \\
\text { whether we can realistically think the student will be ok with being over the } 16 \text { credits. }\end{array}$ \\
\hline Communication & $\begin{array}{l}\text { Respond to students' communication/questions preferably within } 24 \text { hours; but no later } \\
\text { than } 48 \text { hours. If you don't have the answer within that amount of time, please respond } \\
\text { indicating that you will follow-up with the answer so they know you got the } \\
\text { communication and are working on the answer. Then, put the issue on your to-do list as a } \\
\text { reminder that you need to clear the communication. }\end{array}$ \\
$\begin{array}{l}\text { Be a go-between with content coaches when students have praise, concerns, or questions } \\
\text { about a course, etc. to help ensure content coaches' and students' communication is } \\
\text { smooth and informative as needed. }\end{array}$ \\
$\begin{array}{l}\text { Respond to communication with content coaches within } 24 \text { hours (preferably within a } \\
\text { few hours, but no later than } 48 \text { hours to assist with course or student concerns/questions. }\end{array}$ \\
Out-of-the-office Rule:
\end{tabular}




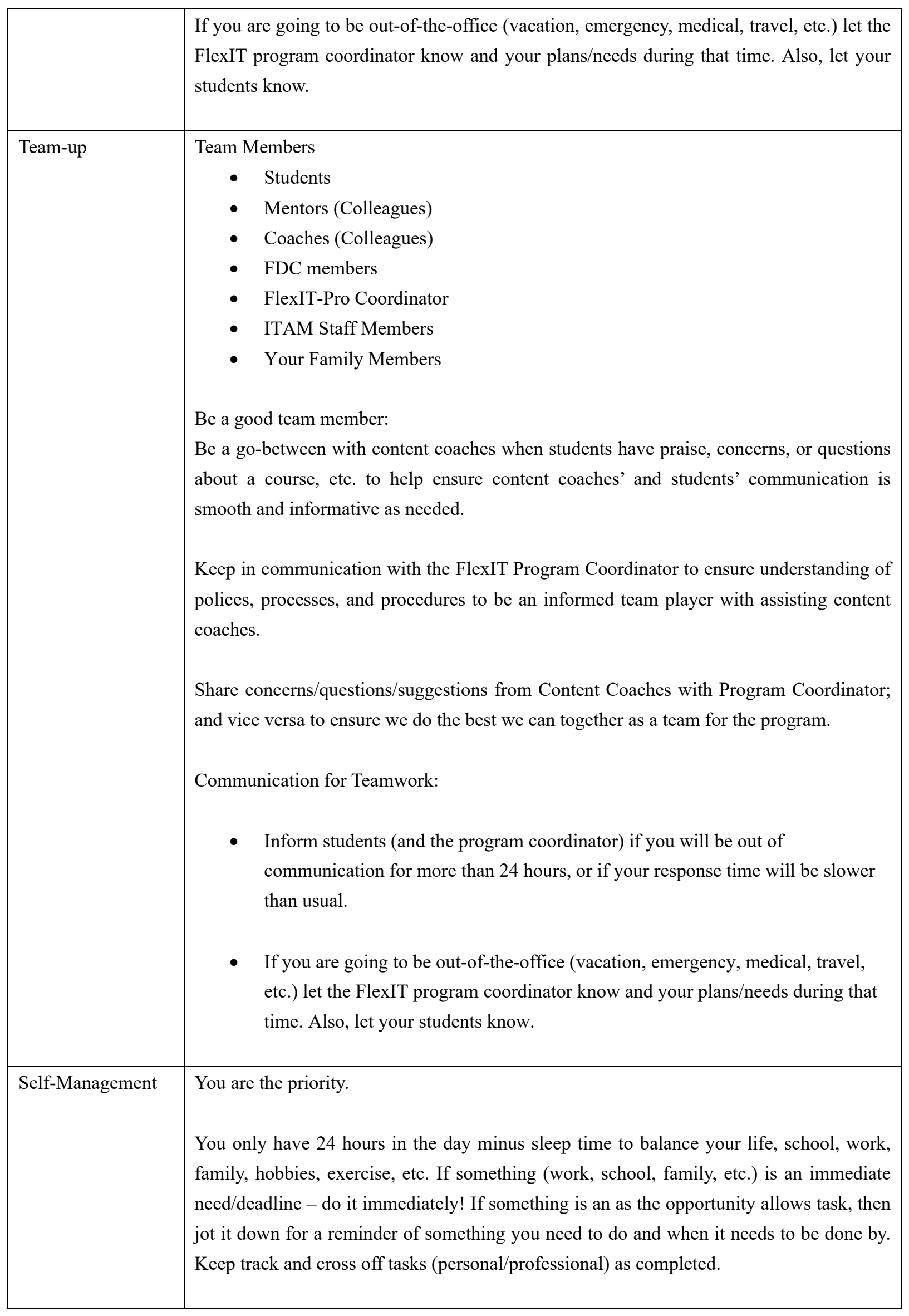




\begin{tabular}{|c|c|}
\hline Assessment & $\begin{array}{l}\text { Pay attention to students' performance and punctuality. } \\
\text { Constantly check students' life situations by offering open and safe communication } \\
\text { modes. } \\
\text { Constantly communicate with coaches. }\end{array}$ \\
\hline $\begin{array}{l}\text { Career } \\
\text { Development }\end{array}$ & $\begin{array}{l}\text { Write down your own experience and knowledge about career preparations. Use the } \\
\text { information to support students. } \\
\text { Apply knowledge from your own expertise development activities (conferences, training, } \\
\text { etc.) when you consult with students regarding their career preparation. } \\
\text { Find professionals who can support your students' career development. }\end{array}$ \\
\hline Life expertise & $\begin{array}{l}\text { Write down your life experience. } \\
\text { Do something out of your routines (Volunteers or trips, etc) } \\
\text { Have a small notebook to record what you experienced, felt, and acted today. } \\
\text { Socialize with our advisory board members to access the latest industrial situations and } \\
\text { develop human network. }\end{array}$ \\
\hline
\end{tabular}

\section{Copyright Disclaimer}

Copyright reserved by the authors.

This article is an open-access article distributed under the terms and conditions of the Creative Commons Attribution license (http://creativecommons.org/licenses/by/4.0/). 